\title{
Factors Affecting Teachers' Resiliency Amidst the COVID-19 Pandemic
}

\author{
Kevin T. Lagat \\ Biliran Province State University, Biliran, Philippines, \\ https://orcid.org/0000-0002-1272-5653 \\ Email Correspondence: kt.lagat@bipsu.edu.ph
}

\begin{abstract}
Despite the threat of the COVID-19 pandemic, teachers continue to navigate the new normal in education which demonstrate their resilience. This descriptive correlational study determined the level of optimism, job stress, and emotional exhaustion of 150 teachers amidst the COVID-19 pandemic, and it analyzed the relationship among these three variables. The data were analyzed using weighted mean, standard deviation, and Pearson r. Results revealed resiliency among teachers amidst the pandemic with a high level of optimism and a relatively low COVID-19 induced job stress and emotional exhaustion level. This study has also shown that optimism is not correlated with job stress and emotional exhaustion, but it found out significant relationship between the last two variables. Generally, it can be concluded that teachers are highly optimistic amidst the pandemic. This paper also validates earlier claims that lower levels of job stress contribute to lower incidents of emotional exhaustion.
\end{abstract}

Keywords: education, resiliency, optimism, job stress, emotional exhaustion, descriptive correlational

\subsection{Introduction}

The COVID-19 pandemic is a crisis that challenged humanity's resilience. It brought an immense impact around the world to many sectors such as tourism, agriculture, transportation, and even politics (Chidume et al., 2021; Gkiotsalitis, 2021; Wong et al., 2020; Workie et al., 2020; Yang et al., in press). It has also caused unprecedented challenges in the education sector (Liguori \& Winkler, 2020) wherein, Schools were forced to abruptly close their doors (Teymori \& Fardin, 2020) because the mass gathering of students, teachers, and other school personnel can result in the rapid transmission of the virus (Askitas et al., 2020; Auger, et al., 2020). Thus, the pandemic has affected $70 \%$ of the world's student population (United Nations Educational, Scientific and Cultural Organization
[UNESCO], 2020a), widened the gap of learning equality (Jæger \& Blaabæk, 2020), disrupted class activities (J. L. N. Upoalkpajor \& Upoalkpajor, 2020), and undermined the academic achievement of students (Kuhfeld et al., 2020).

Despite the challenges brought by the pandemic and its impact on the education sector, innovations and countermeasures were introduced and implemented to adapt to the demands of the current time. Schools shifted to remote learning modalities, like some countries have resorted to complete online education or virtual learning (Teymori \& Fardin, 2020; Torres-Martín et al., 2021) home-based learning (Mansor et al., 2021), and applied alternative academic calendars (UNESCO, $2020 \mathrm{~b}$ ) to continue the teaching and learning process. 
Educational institutions have also initiated necessary countermeasures to facilitate teaching and learning amidst the pandemic, like employing online learning and distance learning modalities (Toquero, 2020). Specifically, the country has implemented a flexible learning (FL) approach for higher education and blended learning (BL) for basic education. FL is a learner-centered pedagogy that provides teachers and learners equal options of flexibility in terms of pace, place, process, and product of learning (Huang et al., 2020; Joan, 2013) by integrating technologies (Cassidy et al., 2016). On the other hand, BL combines face-to-face and technology-mediated learning to overcome both teachers and learners geographical proximity or limitations (Siemens et al., 2015). In the country's current context, schools primarily provided learners and teachers with two primary options: online learning modality and modular distance learning.

Both online and modular modalities require the crafting and reproduction of learning modules or pockets instead of the traditional textbooks. These activities ensure that students' lessons are synthesized and packaged from the content of the tasks to the assessment. For students who have chosen modular distance learning, the teachers distribute learning pockets to their houses or barangays. Modules are retrieved based on the schedule. In this modality, the teachers' lives are at stake since they are constantly exposed to possible COVID-19 transmission.

On the other hand, learning materials will be uploaded in a Learning Management System (LMS) like Google Classroom, MOODLE, and Canvas in the online modality. The students can download them and answer the assessments. Under this modality, teachers need to learn technology-based instruction to facilitate teaching and learning effectively. However, for teachers who have been used to traditional face-to-face instruction and have low or intermediate computer competency, the adjustment is considered very difficult (Gering \& Kiraly, 2020; Gillett-Swan, 2017; Lagat, 2020; Moralista \& Oducado, 2020).

Undeniably, the pandemic has forced teachers to work harder than ever to continue teaching amidst the virus' disruption and threat. Several studies have revealed the challenges and difficulties faced by teachers and school administrators in the new normal of education (Asio \& Bayucca, 2021; Garg et al., 2020; Süğümlü, 2021). Hence, the COVID-19 pandemic has added stress to the work of teachers in the new normal. It brought risks for teachers' physical, mental, spiritual, and emotional well-being (Dabrowski, 2020).

Several studies have noted that stress, burnout, and emotional exhaustion affect the mental and physical well-being of the teachers as well as their performance at work (Atmaca et al., 2020; Khan et al., 2012; Wangui et al., 2013). Other studies supported this, claiming that stress and emotional exhaustion cause workers to be less motivated and energetic at work. They are factors that decrease their satisfaction, productivity, performance and sometimes make them deviant (Fernandez-Castro et al., 2017; Golparvar et al., 2012).

Amidst the challenges in the new normal of education, teachers' resiliency despite the threat of the virus seemed to be an unexplored area. However, resilience is a known trait of Filipinos (Reyes et al., 2019). It pertains to the person's ability to adapt, and be flexible amidst adversities, and endure challenges successfully (Agaibi \& Wilson, 2005; Zautra et al., 2012), and it is considered as an innate defense mechanism of individuals (Masten \& Reed, 2002). Thus, it is crucial to conduct studies that would explore factors that increase teachers' resiliency in the new normal, particularly amidst COVID-19 related job stress and emotional exhaustion.

For the study, the paper focused on optimism as one of a person's assets that are positively correlated with resiliency (Carver et al., 2010; 
Gomez-Mollnero et al., 2018; Reyes et al., 2019; Souri \& Hasanirad, 2011). Furthermore, since it is an individual characteristic to expect something good will happen in the future, it enables a person to withstand anxiety and fear (Carver et al., 2010; Scheier \& Carver, 1985).

Özdemir and Kerse (2020), in their study, pointed out that optimism has a negative direct and indirect effect on stress and emotional exhaustion among health care workers exposed to risks and concluded that optimism is a component of resiliency. Optimism is also seen as a predictor of resiliency among first-year students. They transition their lives into a more challenging and stressful environment in a university that sometimes causes psychological distress (GomezMollnero et al., 2018).

Furthermore, the study conducted by Reyes, et al. (2019) about the resiliency of military personnel in active duty has shown that self-esteem and optimism are factors that contribute to a lower level of distress while in service. The study conducted by the Philippine Survey Research Center, as cited (Parrocha, 2020), also showed that the majority of Filipinos are optimistic and that the country can overcome the pandemic. However, it did draw out implications of how being optimistic can affect the well-being and resiliency of Filipinos amidst this crisis. At present, limited literature has explored how optimism helped teachers be resilient amidst COVID-19 induced job stress and emotional exhaustion.

In this context, the study aimed to determine the level of optimism, job stress, and emotional exhaustion of basic education teachers, especially when grouped according to demographics such as their generational age and gender. It also sought to analyze the relationship between optimism and COVID-19 induced job stress and emotional exhaustion. The findings of this will contribute to research studies related to the impact of the COVID-19 pandemic in the education sector and provide baseline data for school administrators to develop interventions to promote the well-being of teachers.

\section{Framework of the Study}

This paper is chiefly anchored on the resiliency theory developed by Fergus and Zimmerman (2005), which highlighted assets and resources as primary factors of adult resiliency. Resources in this theory pertain to external factors like parental support and mentoring. At the same time, assets refer to intrinsic factors such as selfesteem, competence, optimism that help persons overcome the adverse effects of risks like fear and burnout (Fergus \& Zimmerman, 2005).

In this study, the researcher only focused on one asset of resiliency, which is optimism. This is because it is taken as an individual asset regarded as the opposite of hopelessness (Alloy et al., 2006) and a favorable disposition and mindset that something will have a positive outcome (Panchal et al., 2016). Moreover, studies have shown that optimists tend to be positive in life, making them persistent and confident in the face of uncertainties (Carver et al., 2010) making individuals less vulnerable to stress and anxiety, which causes psychological distress. Thus, the preceding literature affirms and offers theoretical and conceptual perspectives to the investigation of optimism among teachers as a potent factor of resiliency amidst COVID-19 induced job stress and emotional exhaustion.

\subsection{Methodology}

This quantitative study utilized descriptive and correlational research design since it described the variables and their relationships (Sousa et al., 2007). For example, the descriptive approach determined optimism and job stress, while the correlational approach identified the relationship among these three (3) variables.

The respondents of this study were 150 
basic education teachers from the Department of Education (DepEd), Biliran Division. Due to complications at this time in doing random sampling, the respondents were selected using referral and purposive sampling methods. The criteria for the inclusion of a respondent were his/ her affiliation to a basic education institution, and he/she should be actively teaching during the pandemic.

To gather the data, the researcher used with permission the following: the 5-item optimismpessimism instrument; the 8-item job stress instrument; and the 9-item emotional exhaustion instrument by Özdemir and Kerse (2020). In addition, its applicability to the local setting was validated by a Social Science Professor, a Socio-linguistic Professor, and a Psychometrician using a survey instrument validation rating scale developed by Oducado (2020). The validation yielded a mean score of 4.51. Meanwhile, the questionnaire's reliability was tested by conducting a pilot test with 30 teachers and yielded a reliability index of 0.930, 0.887, and 0.914 using Cronbach's Alpha.

All these research instruments were prepared in 5-point Likert scale ( 1 = Strongly Disagree, $2=$ Disagree, 3 = Neutral, $4=$ Agree, $5=$ Strongly Agree) tailored in the context of COVID-19 pandemic. The researcher utilized descriptive and inferential analyses using appropriate statistical tools. Mean, Standard Deviation, and Pearson $r$ productmoment correlation were used as a statistical treatment of the data.

Before the study commenced, the informed consent of the respondents was requested and secured first. They were informed that they have the right to choose not to participate or withdraw from the study and were assured that their identity would not be divulged. Following the approval, responses of the respondents were collected by sending the link of a google form- a web-based application used to create forms to collect data- where the instruments were attached to the FACEBOOK messenger or email of the respondents. This action is due to restrictions on face-to-face meetings. Confidentiality of the data gathered was observed by making sure that the responses were properly stored and protected.

\subsection{Results and Discussion}

Table 1 presents the level of optimism of basic education teachers amidst the pandemic. Based on the result, teachers generally, have a very high level of optimism amidst the COVID-19 pandemic $(M=4.49, S D=.720)$. It also shows that when respondents were grouped according to their generational age, teachers who belonged to Baby Boomers age group have relatively low level of optimism ( $M=4.18, S D=.957)$ when compared to Generation X ( $M=4.27, S D=.913)$, and Generation $Y(M=4.63, S D=.538)$. It can also be noted that the male respondents exhibited a higher level of optimism ( $M=4.67, \mathrm{SD}=.419)$ than the female respondents $(M=4.45, S D=.768)$.

Table 1. Level of Teachers' Optimism

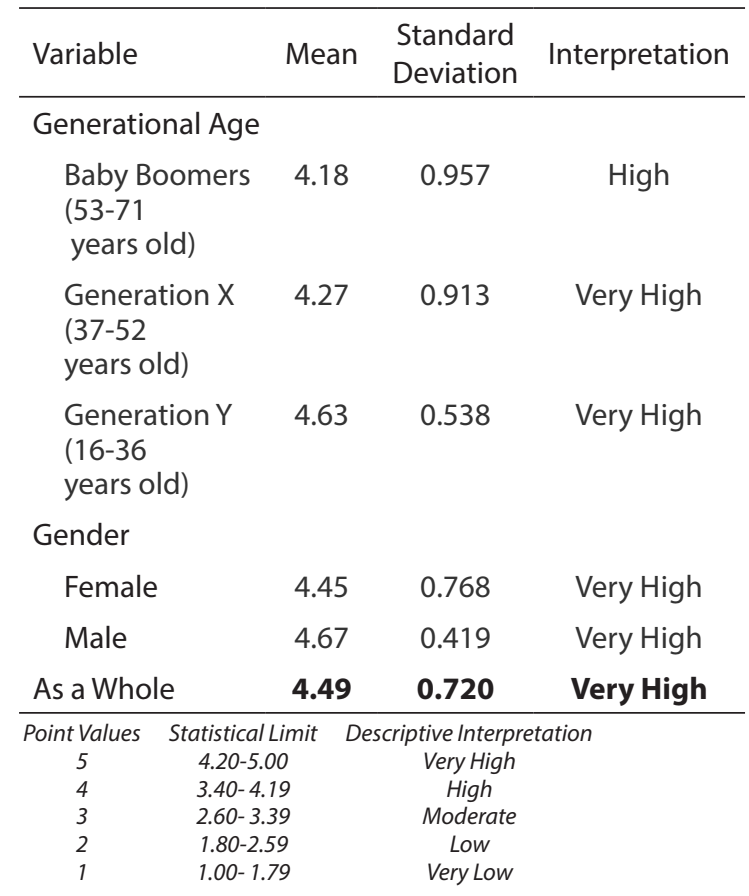


The data means that despite the threat and challenges brought by the virus, teachers remain very hopeful and optimistic that everything will be okay someday. This kind of mindset could be attributed to the news on the successful trials of the COVID-19 vaccine. This development raised hope among many people that the pandemic will end soon. It can also be credited to how Filipino teachers positively accept that difficulties and challenges are common in the teaching profession (Viernes \& de Guzman, 2005).

Other than this, optimism and resilience are also common traits among Filipino teachers and are considered their competitive advantage (Reyes $\&$ Valencia, 2014). Apart from teachers, Reyes, et al. (2019) also pointed out that active Filipino military personnel remain optimistic with high self-esteem even amidst physical and mental distress. The religiosity and spirituality of Filipinos can also be attributed to the high level of optimism among teachers. The studies conducted by Obligacion (1997) and Basileyo (2019) noted that faith or spirituality is a predictor of psychological wellbeing and positive expectancies.

The result in Table 1 also implied that teachers of advanced age are less optimistic than younger teachers. This result is corroborated with the findings of the study conducted by Mishra (2013) and Martinez-Moreno, et al. (2020), which revealed that younger adults are more optimistic than older ones. One possible reason for this is that older teachers are more vulnerable to the virus than younger adults. In addition, the study of R. Lekamwasam and Lekamwasam (2020) indicated that the adverse effects COVID-19 pandemic are more severe to vulnerable populations, especially older adults, because of higher risks of transmission and complications.
On the other hand, the result revealed that male teachers are quite more optimistic amidst the pandemic than female teachers. This result is supported by the Bjuggren and Elert (2019) study, which elucidated that females are less optimistic than males but contradicted the study of Mishra (2013), which considered females to be more optimistic than males. However, perhaps the slight difference in the level of optimism among the two genders is due to the difference how they react to the threat of the pandemic; females tend to be more anxious than males (Martinez-Moreno et al., 2020).

The data in Table 2 indicates the level of COVID-19 induced job stress and emotional exhaustion among teachers. The result shows that teachers as a whole have experienced a moderate level of COVID-19 induced job stress ( $M=2.85$, SD $=.806)$ and emotional exhaustion $(\mathrm{M}=2.70, \mathrm{SD}=$ .773). When respondents were grouped according to their generational age, Baby Boomers experienced the highest level of job stress ( $M=3.13, S D=.910)$, while respondents categorized under Generation $X(M=2.79, S D=.817)$ and Generation $Y(M=2.84$, $S D=2.79$ ) have shown lower levels of job stress. In terms of emotional exhaustion, Baby Boomers felt more emotionally exhausted because of COVID-19 $(\mathrm{M}=2.77, \mathrm{SD}=.928)$ than Generation $X(\mathrm{M}=2.69$, $\mathrm{SD}=.778)$ and Generation $\mathrm{Y}(\mathrm{M}=2.70, \mathrm{SD}=.761)$. It can also be noted when respondents are grouped according to their gender, female respondents have recorded a higher level of COVID-19 related job stress $(M=2.89, S D=.814)$ than male respondents $(M=$ $2.67, \mathrm{SD}=.755)$. In terms of the level of emotional exhaustion, the data shows that male respondents have reported higher level of emotional exhaustion $(M=2.74, S D=.814)$, than female respondents $(M=$ $2.69, \mathrm{SD}=.767)$. 
Table 2. Level of Teachers' Job Stress and Emotional Exhaustion

\begin{tabular}{|c|c|c|c|c|c|c|c|}
\hline \multirow{2}{*}{\multicolumn{2}{|c|}{ Variables }} & \multicolumn{3}{|c|}{ Job Stress } & \multicolumn{3}{|c|}{ Emotional Exhaustion } \\
\hline & & M & SD & Interpretation & M & SD & Interpretation \\
\hline \multicolumn{8}{|c|}{ Generational Age } \\
\hline \multicolumn{2}{|c|}{$\begin{array}{l}\text { Baby Boomers } \\
\text { (53-71 years old) }\end{array}$} & 3.13 & 0.910 & Moderate & 2.77 & 0.928 & Moderate \\
\hline \multicolumn{2}{|c|}{$\begin{array}{l}\text { Generation } X \\
\text { (37-52 years old) }\end{array}$} & 2.79 & 0.817 & Moderate & 2.69 & 0.778 & Moderate \\
\hline \multicolumn{2}{|c|}{$\begin{array}{l}\text { Generation } Y \\
\text { (16-36 years old) }\end{array}$} & 2.84 & 0.790 & Moderate & 2.70 & 0.761 & Moderate \\
\hline \multicolumn{8}{|l|}{ Gender } \\
\hline \multicolumn{2}{|c|}{ Female } & 2.89 & 0.814 & Moderate & 2.69 & .767 & Moderate \\
\hline \multicolumn{2}{|l|}{ Male } & 2.67 & 0.755 & Moderate & 2.74 & .814 & Moderate \\
\hline \multicolumn{2}{|c|}{ As a Whole } & 2.85 & 0.806 & Moderate & 2.70 & 0.773 & Moderate \\
\hline $\begin{array}{c}\text { Point Values } \\
5 \\
4 \\
3 \\
2 \\
1\end{array}$ & $\begin{array}{c}\text { Statistical Limit } \\
4.20-5.00 \\
3.40-4.19 \\
2.60-3.39 \\
1.80-2.59 \\
1.00-1.79\end{array}$ & $\begin{array}{r}\text { Descriptive } \\
V e \\
M c \\
V e\end{array}$ & $\begin{array}{l}\text { terpretation } \\
\text { High } \\
\text { gh } \\
\text { erate } \\
\text { w } \\
\text { Low }\end{array}$ & & & & \\
\hline
\end{tabular}

This is alarming considering that high level of job stress and emotional exhaustion of teachers are associated with counterproductive behaviors, low job satisfaction, negative physical and mental well-being (Atmaca et al., 2020; Khan et al., 2012; Wangui et al., 2013). In turn, all these affect the achievements and well-being of students under the teachers' care.

The result also implies that the pandemic has a higher impact on older teachers than younger ones when it comes to job stress and emotional exhaustion. This is probably because the pandemic has forced older teachers to instantly adapt to a new normal setting, where schools have shifted from traditional classrooms to a technologymediated learning environment. Several studies have pointed out that older teachers used to the conventional learning environment find it difficult and discomforting to adjust abruptly to the new learning environment (Géring \& Király, 2020; Hardy, 2010; Sheriffdeen, 2007). On the other hand, younger teachers can quickly adapt to the new normal setting since, generally speaking, they are more used to using technology like computers. As a result, these young teachers are more exposed to applications utilized in teaching as their learning aids. Therefore, school administrators should initiate interventions to mitigate or counter COVID-19 related job stress and emotional exhaustion among teachers, especially those of advanced age.

This study also depicted a higher level of job stress to female teachers than male teachers in the new normal. This result is supported by several studies which have claimed female workers tend to report a higher level of stress and burnout at work (Marchand et al., 2018; Purvanova \& Muros, 2010). The probable reason for the high level of COVID19 related job stress among female teachers is that females tend to be more anxious than males in times of distress, as indicated in several literature reviews (Hou et al., 2020; Martinez-Moreno et al., 
2020). However, based on Table 2, male teachers have felt more emotionally exhausted than female teachers due to COVID -19. This result challenged the common findings of several studies showing that females tend to feel more emotionally exhausted than males (Alonso et al., 2020; Marchand et al., 2018; Palupi \& Findyartini, 2019). A popular notion probably because male teachers do the heavy physical work at school carrying and delivering the learning modules to students. Such tasks demand more effort and energy from male teachers, which could lead to stress and burnout. .

Pearson $r$ product-moment correlation was used to determine the relationship of Optimism, Job Stress, and Emotional Exhaustion of teachers. Results of the correlation matrix in Table 3 reveals there is an inconclusive evidence that teacher's optimism, COVID-19 induced job stress ( $r=-090$, $p=0.275)$ and emotional exhaustion $(r=0.001$, $p=0.993$ ) are significantly correlated. However, significant relationship was found between job stress and emotional exhaustion $(r=0.738, p=$ $<.001)$.

Table 3. Relationship of Optimism, Job Stress, and Emotional Exhaustion

\begin{tabular}{|c|c|c|c|}
\hline Variables & Optimism & $\begin{array}{l}\text { Job } \\
\text { Stress }\end{array}$ & $\begin{array}{l}\text { Emotional } \\
\text { Exhaustion }\end{array}$ \\
\hline
\end{tabular}

Optimism

Job Stress $\quad-0.090$

Emotional $\quad 0.001 \quad 0.738^{* * *}$

Exhaustion

Note: ${ }^{*} p<.05,{ }^{* *} p<.01,{ }^{* * *} p<.001$

This means teachers' optimism, COVID-19 induced job stress, and emotional exhaustion based on the findings of this study are independent of each other. This result contradicts the earlier findings of several studies, which elucidated that there is a significant negative correlation between optimism, job stress, and emotional exhaustion (Britton et al., 2019; Özdemir \& Kerse, 2020). This is because of the individual differences in resilience, coping, and perceptions that may influence how a person responds to negative experiences (Arslan et al., 2020).

On the other hand, this study revealed that job stress and emotional exhaustion are positively associated. This result is corroborated by Özdemir and Kerse's (2020) study, which elucidated that COVID-19 related job stress and emotional exhaustion are significantly associated. Furthermore, other studies have also noted that stress and emotional exhaustion are significantly associated with affecting work performance (Alonso et al., 2020) and professional efficacy (Marchand et al., 2018). Thus, the low-level COVID-19 related emotional exhaustion of teachers in this study, can be attributed to the low COVID-19 induced job stress level.

\subsection{Conclusion}

Based on the findings of this study, it can be concluded that teachers are highly optimistic amidst the pandemic with a relatively lower level of COVID-19 induced job stress and emotional exhaustion. Furthermore, this paper also validated earlier claims that lower levels of job stress contribute to lower incidents of emotional exhaustion. Therefore, it is recommended that interventions be done to promote the well-being of teachers amidst the pandemic, especially the older teachers, since they are more vulnerable to the threat of the virus and are more likely to experience job stress and emotional exhaustion.

\section{Recommendations}

Given the study's finding, it is strongly recommended that school administrators extend support and interventions in the new normal, particularly among teachers of advanced age, who 
are more vulnerable to the threat of the virus and are more likely to experience job stress emotional exhaustion. Faculty development interventions may also focus on increasing teachers' optimism not just during this pandemic, but all the time. In addition, future researchers interested in teachers' resiliency amidst this pandemic may explore external factors that contribute to coping in the new normal.

\section{References}

Agaibi, C., \& Wilson, J. P. (2005). Trauma, PTSD, and resilience: A review of the literature. Trauma, Violence, \& Abuse, 6(3), 195-216. https://doi. org/10.1177/1524838005277438

Alloy, L. B., Abramson, L. Y., Whitehouse, W. G., Hogan, M. E., Panzarella, C., \& Rose, D. T. (2006). Prospective incidence of first onsets and recurrences of depression in individuals at high and low cognitive risk for depression. Journal of Abnormal Psychology, 115(1), 145- 156. https://doi.org/10.1037/0021843X.115.1.145

Alonso, F., Esteban, C., Gonzalez-Marin, A., Alfaro, E., \& Useche, S. (2020). Job stress and emotional exhaustion at work in Spanish workers: Does unhealthy work affect the decision to drive? PLOS ONE, 15(1), e0227328. https://doi. org/10.1371/journal.pone.0227328

Alves, R., Lopes, T., \& Precioso, J. (2020). Teachers' well-being in times of Covid-19 pandemic: Factors that explain professional well-being. International Journal of Educational Research and Innovation, 15, 203-217. https://doi. org/10.46661/ijeri.5120

Arslan, G., Yıldırım, M., Tanhan, A., Buluş, M., \& Allen, K.-A. (2020). Coronavirus stress, optimism- pessimism, psychological inflexibility, and psychological health: Psychometric properties of the Coronavirus stress measure. International Journal of Mental Health and Addiction, 4, 1-17. https://doi.org/10.1007/ s11469-020-00337-6

Asio, J. M., \& Bayucca, S. A. (2021). Spearheading education during the COVID-19 rife: Administrators' level of digital competence and schools'readiness on distance learning. Journal of Pedagogical Sociology and Psychology, 3(1), 19-26. http://www.doi. org/10.33902/JPSP.2021364728

Askitas, N. T., Tatsiramos, K., \& Verheyden, B. (2020). Lockdown strategies, mobility patterns, and covid-19 [IZA Discussion Paper No. 13293]. Institute of Labor and Economics. https:// www.iza.org/publications/dp/13293/ lockdown-strategies-mobility-patterns-andcovid-19

Atmaca, Ç., Rızaoglu,F.,Türkdogan,T.,\&Yaylı,D.(2020). An emotion focused approach in predicting teacher burnout and job satisfaction. Teaching and Teacher Education, 90, 103025 https://doi. org/10.1016/j.tate.2020.103025

Auger, K. A., Shah, S. S., Richardson, T., Hartley, D., Hall, M., Warniment, A., Timmons, K., Bosse, D., Ferris, S. A., Brady, P. W., Schodelmeyer, A.C., \& Thompson, J. E. (2020). Association between state-wide school closure and COVID-19 incidence and mortality in the US. JAMA, 324(9), 859-870. https://doi.org/10.1001/ jama.2020.14348

Basileyo, A. E. (2019). Spirituality and psychological well-being: The mediating role pessimism. LPU-Laguna Journal of Multidisciplinary Research, 3(3), 26-41. https://www. 
researchgate.net/publication/333797461_ Spirituality_and_Psychological_Well-being_ The_Mediating_Role_of_Pessimism

Bjuggren, C. M., \& Elert, N. (2019). Gender differences in optimism. Applied Economics, 51(47), 5160-5173. https://doi.org/10.1080/0 0036846.2019 .1610714

Britton, M., LaLonde, L., Oshio, A., \& Taku, K. (2019). Relationships among optimism, pessimism, and posttraumatic growth in the US and Japan: Focusing on varying patterns of perceived stressfulness. Personality and Individual Differences, 151(1), 109513. https:// doi.org/10.1016/j.paid.2019.109513

Carver, C. S., Scheier, M. F., \& Segerstrom, S. C. (2010). Optimism. Clinical Psychology Review, 30(7), 879-889. https://doi.org/10.1016/j. cpr.2010.01.006

Cassidy, A., Fu, G., Valley, W., Lomas, C., Jovel, E., \& Riseman, A. (2016). Flexible learning strategies in first through fourth-year course (EJ1104490). ERIC. https://files.eric.ed.gov/ fulltext/EJ1104490.pdf

Chidume, C. G., Oko-Otu, C. N., \& Aro, G. C. (2021). State fragility and COVID-19 pandemic: Implications on the political economy of Nigeria. Social Sciences \& Humanities Open, 3(1),11127. https://doi.org/10.1016/j. ssaho.2021.100127

Dabrowski, A. (2020). Teacher wellbeing during a pandemic: Surviving or thriving? Social Education Research, 2(1), 35-40. https://doi. org/10.37256/ser.212021588

Ferdig, R., Baumgartner, E., Hartshorne, R., KaplanRakowski, R., \& Mouza, C. (Eds.). (2020).
Teaching, technology, and teacher education during the COVID-19 pandemic: Stories from the field. Association for the Advancement of Computing in Education (AACE). https:// www.learntechlib.org/p/216903/.

Fergus, S., \& Zimmerman, M. (2005). Adolescent resilience: A framework for understanding healthy development in the face of risk. Annual Review of Public Health, 26(1), 399$419 . \quad$ https://doi.org/10.1146/annurev. publhealth.26.021304.144357

Fernandez-Castro, J., Martinez-Zaragoza, F., Rovira, T., Edo, S., Solanes-Puchol, Á., Del Río, B. M., Garcia-Siera, R., Benavides-Gil, G., \& Doval, E. (2017). How does emotional exhaustion influence work stress? Relationships between stressor appraisals, hedonic tone, and fatigue in nurses' daily tasks: A longitudinal cohort study. International Journal of Nursing Studies, 75, 43-50. http://dx.doi.org/10.1016/j. ijnurstu.2017.07.002

Garg, S., Aggarwal, D., Upadhyay, S. K., Kumar, G., \& Singh, G. (2020). Effect of COVID-19 on school education system: Challenges and opportunities to adopt online teaching and learning. Humanities \& Social Sciences Reviews, 8(6), 10-17. https://doi.org/10.18510/ hssr.2020.862

Gering, Z., \& Kiraly, G. (2020). Challenges in teaching andlLearning- the challenges of flexible learning: Vol. 2. Decline or renewal of higher education?Threats and possibilities amidst a global epidemic situation. Future of Higher Education Research Center, Budapest Business School. https://www.researchgate. net/publication/341179378_CHANGES_ IN_TEACHING_AND_LEARNING_THE_ CHALLENGES_OF_FLEXIBLE_LEARNING_ 
Decline_or_renewal_of_higher_education_ Threats_and_possibilities_amidst_a_global_ epidemic_situation_Horizon_Scanning_ Report_Series

Gillett-Swan, J. (2017). The challenges of online learning: Supporting engaging the isolated learner. Journal of Learning Design, 10(1), 2030. https://www.jld.edu.au/article/view/293. html

Gkiotsalitis, K. (2021). A model for modifying the public transport service patterns to account for the imposed COVID-19 capacity. Transportation Research Interdisciplinary Perspectives, 9, 100336. https://doi.org/10.1016/j.trip.2021.100336

Golparvar, M., Kamkar, M., \& Javadian, Z. (2012). Moderating effects of job stress in emotional exhaustion and feeling of energy relationships with positive and negative behaviors: Job stress multiple functions approach. International Journal of Psychological Studies, 4(4), 99-112. https://doi.org/10.5539/ijps. v4n4p99

Gomez-Mollnero, R., Zayas, A., Ruiz-González, P., \& Guil, R. (2018). Optimism and resilience among university students. International Journal of Developmental and Educational Psychology, 1(1), 147-154. https://doi.org/10.17060/ ijodaep.2018.n1.v1.1179

Hardy, I. J. (2010). Teacher talk: Flexible delivery and academics' praxis in an Australian university. International Journal for Academic Development, 15(2), 131-142. https://doi. org/10.1080/13601441003738277

Hou, F., Bi, F., Jiao, R., Luo, D., \& Song, K. (2020). Gender differences of depression and anxiety among social media users during the
COVID-19 outbreak in China: A crosssectional study. BMC Public Health, 20(1), 1648. https:// doi.org/10.1186/s12889-020-09738-7

Huang, R. H., Liu, D. J., Tlili, A., Yang, J., \& Wang, H. (2020). Handbook on facilitating flexible learning during educational disruption: The Chinese experience in maintaining undisrupted learning in COVID-19 outbreak. https://iite.unesco.org/wp-content/ uploads/2020/03/Handbook-on-FacilitatingFlexible-Learning-in-COVID-19-OutbreakSLIBNU-V1.2-20200315.pdf

Jæger, M., \& Blaabæk, E. (2020). Inequality in learning opportunities: Evidence from library takeout. Research in Social Stratification and Mobility, 68, 100524 https://doi.org/10.1016/j. rssm.2020.100524

Joan, R. (2013). Flexible learning design in classroom to promote quality education. Journal on School Educational Technology, 9(1), 37-42. https://doi.org/10.26634/jsch.9.1.2401

Khan, A., Shah, I. M., Khan, S., \& Gul, S. (2012). Teachers' stress, performance \& resources: The moderating effects of resources on stress \& performance. International Review of Social Sciences and Humanities, 2(2), 21-29. file:///C:/ Users/imc-main/Downloads/ppr1.pdf

Kuhfeld, M., Soland, J., Tarasawa, B., Johnson, A., Ruzek, E., \& Liu, J. (2020). Projecting the potential impacts of COVID-19 school closures on academic achievement. Educational Researcher, 49(8), 549-565. https://doi. org/10.3102/0013189X20965918

Lagat, K. (2020). Education amidst COVID-19 disruption: Perceived difficulty in implementing flexible learning strategies of 
teacher education faculty members in a state university. Philippine Social Science Journal, 3(3), 142-150. https://doi.org/10.52006/main. v3i3.264

Lekamwasam, R., \& Lekamwasam, S. (2020). Effects of COVID-19 pandemic on health and wellbeing of older people: A comprehensive review. Annals of Geriatric Medicine and Research, 24(3), 166-172. https://doi.org/10.4235/ agmr.20.0027

Liguori, E., \& Winkler, C. (2020). From offline to online: Challenges and opportunities for entrepreneurship education following the COVID-19 pandemic. Entrepreneurship Education and Pedagogy, 3(4), 346-51. https:// doi.org/10.1177/2515127420916738

Mansor, A. N., Zabarani, N. H., Jamaludin, K. A., Mohd Nor, M. Y., Alias, B. S., \& Mansor, A. Z. (2021). Home-based learning (HBL) teacher readiness scale: Instrument development and demographic analysis. Sustainability, 13,(4), 1-15. https://doi.org/10.3390/su13042228

Marchand, A., Blanc, M.-E., \& Beauregard, N. (2018). Do age and gender contribute to workers' burnout symptoms? Occupational Medicine, 68(6), 405411. https://doi.org/10.1093/occmed/kqy088

Martinez-Moreno, A., Ibanez-Pérez, R.J.,Cavas-García, F., \& Cano-Noguera, F. (2020). Older adults' gender, age and physical activity effects on anxiety, optimism, resilience and engagement. International Journal Environmental Research and Public Health, 17(20), 1-15. https://doi. org/10.3390/ijerph17207561

Masten, A., \& Reed, M. (2002). Resilience in development. In C.R. Synder, \& S.J. Lopez
(Eds.), Handbook of positive psychology (pp. 117-131). Oxford University Press.

Mishra, K. K. (2013). Gender and age related differences in optimism and good life. Indian Journal of Social Science Researches, 10(1), 9-17. https://www.researchgate.net/ publication/265683327_Gender_and_ age_related_differences_in_optimism_ and_good_life\#: :text=Analysis\%20of\%20 the $\% 20$ data $\% 20$ revealed,optimism $\% 20$ i n \% $20 \mathrm{fav}$ ar $\% 20$ of $\% 20$ females.\&text $=$ Male $\% 20$ respondents $\% 20$ reported $\% 20$ better $\% 20$ life,to $\% 20$ other $\% 20$ three\%20age\%20groups.

Moralista, R. B., \& Oducado, R.M.F. (2020). Faculty perception toward online education in a state college in the Philippines during the Coronavirus disease 19 (COVID-19) pandemic. Universal Journal of Educational Research, 8(10), 4736 - 4742. https://doi.org/10.13189/ ujer.2020.081044

Obligacion, F. R. (1997). The empowering impact of faith among Filipino women: Implications for development initiatives. International Journal of Sociology of the Family, 27(1), 13-33. https:// www.jstor.org/stable/23070591?seq=1

Oducado, R. M. F. (2020). Survey instrument validation rating scale. https://doi. org/10.13140/RG.2.2.25263.59040

Özdemir, S., \& Kerse, G. (2020). The effects of COVID 19 process on health care workers: Analysing of the relationships between optimism, job stress and emotional exhaustion. International and Multidisciplinary Journal of Social Sciences, 9(2), 178-201. http://doi. org/10.17583/rimcis.2020.5849 
Palupi, R., \& Findyartini, A. (2019). The relationship between gender and coping mechanisms with burnout events in first-year medical students. Korean Journal of Medical Education, 31(4), 331-342. https://doi.org/10.3946/ kjme.2019.143

Panchal, S., Mukherjee, S., \& Kumar, U. (2016). Optimism in relation to well-being, resilience, and perceived Stress. International Journal of Education and Psychological Research, 5(2). http://ijepr.org/panels/admin/papers/256ij1. pdf

Parrocha, A. (2020, April 27). Majority of pinoys optimistic PH can overcome Covid-19 pandemic. Philippine News Agency. https:// www.pna.gov.ph/articles/1101139

Purvanova, R. K., \& Muros, J. P. (2010). Gender differences in burnout: A meta-analysis. Journal of Vocational Behavior, 77(2), 168-185. https://doi.org/10.1016/j.jvb.2010.04.006

Reyes, C. Q., \& Valencia, M. (2014, July 13-19). Competitive edge of migrant Filipino teachers in selected countries [Conference session]. XVIII ISA World Congress of Sociology, Yokohama, Japan. https://www.researchgate.net/ publication/268138812

Reyes, M. E., Dillague, S. G., Fuentes, M. I., Malicsi, C. A., Manalo, D. C., Melgarejo, J. M., \& Cayubit, R. F. (2019). Self-esteem and optimism as predictors of resilience among selected Filipino active duty military personnel in military camps. Journal of Positive Psychology \& Wellbeing, 4(1), 15-25. https://www. journalppw.com/index.php/JPPW/article/ view/159
Scheier, M. F., \&Carver, C.S. (1985). Optimism, coping, and health: Assessment and implicationsof generalized outcome expectancies. Health Psychology, 4(3), 219-247. https://doi. org/10.1037/0278-6133.4.3.219

Sheriffdeen, S. A. S. (2007). Challenges faced by staff and students at tertiary level in flexible learning environment [Master's thesis, Unitec Institute of Technology, NZ]. https:// www.researchbank.ac.nz/bitstream/ handle/10652/1278/fulltext.pdf?sequence $=1$

Siemens, G., Gaševid, D., \& Dawson, S. (2015). Preparing for the digital university: A review of the historyand currentstateofdistance, blended, and online learning. http://linkresearchlab. org/PreparingDigitalUniversity.pdf.

Souri, H., \& Hasanirad, T. (2011). Relationship between resilience, optimism, and psychological well-being of students of medicine. Procedia- Social and Behavioral Sciences, 30, 1541-1544. https://doi. org/10.1016/j.sbspro.2011.10.299

Sousa, V., Driessnack, M., \& Mendes, I. A. C. (2007). An overview of research designs relevant to nursing: Part 1: Quantitative research designs. Revista Latino-Americana de Enfermagem, 15(3), 502-507. https://doi.org/10.1590/ s0104-11692007000300022

Süğümlü,Ü. (2021). A case study on teaching Turkish through distance education. International Journal of Psychology and Educational Studies , 8(1), 174-190. http://dx.doi.org/10.17220/ ijpes.2021.8.1.278

Teymori, A. N., \& Fardin, M. A. (2020). COVID-19 and educational challenges: A review of the 
benefits of online education. Annals of Military and Health Sciences Research, 18(3),105778. https://doi.org/10.5812/amh.105778

Toquero, C. M. (2020). Challenges and opportunities for higher education amid the COVID-19 pandemic: The Philippine context. Pedagogical Research, 5(4),1-5. https://doi. org/10.29333/pr/7947

Torres- Martín, C., Acal, C., El Honrani, M., \& Mingorance Estrada, Á.C. (2021). Impact on the virtual learning environment due to COVID-19. Sustainability, 13,(582), 1-16. https://doi.org/10.3390/su13020582

United Nations Educational, Scientific and Cultural Organization [UNESCO] . (2020, March 19 a). Half of world's student population not attending school: UNESCO launches global coalition to accelerate deployment of remote learning solutions. https://en.unesco.org/ news/half-worlds-student-population- $\% 20$ not-attending-school-unesco-launchesglobal-coalition-accelerate

United Nations, Educational Scientific and Cultural Organization [UNESCO]. (2020, April b). Re-opening schools after COVID-19 closures: Webinars by UNESCO, UNICEF and the World Bank. https://en.unesco.org/news/ framework-reopening-schools

Upoalkpajor, J.-L. N., \& Upoalkpajor, C. B. (2020). The impact of COVID-19 on education in Ghana. Asian Journal of Education and Social Studies, 9(1), 23-33. https://doi.org/10.9734/ AJESS/2020/v9i130238

Viernes, R. M., \& de Guzman, A. B. (2005). Filipino teachers' experiences of supportive relationships with colleagues: A narrative- biographical inquiry. Asia Pacific Education Review, 6(2), 137-142. https://doi.org/10.1007/ BF03026781

Wangui, M. F., Ombui, K., \& Iravo, M. (2013). Effects of work-related stress on teachers performance in public secondary schools in KikuyuSub County, Kenya. International Journal of Science and Research, 5(5), 1645-1651. https://www. ijsr.net/archive/v5i5/20051601.pdf

Wong, A. Y.-Y., Ling, S. K.-K., Louie, L. H.-T., Law, G. Y.-K., So, R. C.-H., Lee, D. C.-W., Yau, F. C-F., \& Yung, P. S.-H. (2020). Impact of the COVID-19 pandemic on sports and exercise. Asia-Pacific Journal of Sports Medicine, Arthroscopy, Rehabilitation and Technology, 22, 39-44. https://doi.org/10.1016/j.asmart.2020.07.006

Workie, E., Mackolil, J., Nyika, J., \& Ramadas, S. (2020). Deciphering the impact of COVID-19 pandemic on food security, agriculture,and livelihoods: A review of the evidence from developing countries. Current Research in Environmental Sustainability, 2, 100014. https://doi.org/10.1016/j.crsust.2020.100014

Yang, Y., Altschuler, B., Liang, Z., \& Li, X. (in press). Monitoring the global COVID-19 impact on tourism: The COVID19 tourism index. Annals of Tourism Research. https://doi.org/10.1016/j. annals.2020.103120

Zautra, A. J., Hall, J. S., \& Murray, K. E. (2010). Resilience: A new definition of health for people and communities. In J. W. Reich, A. Zautra, \& J. S. Hall. (Eds.), Handbook of adult resilience (pp. 3-34). https://books.google. com.ph/books?id=lyRc8ZshU98C\&printsec $=f$ rontcover\&source=gbs_ge_summary_r\&cad $=0 \# v=$ onepage $\& q \& f=f a l s e$ 